\title{
ANALISIS PENGEMBANGAN USAHA KUE KHAS TE'TEKAN DI KABUPATEN ENREKANG
}

\author{
Oleh \\ A.Siti Nurul Izzati' ${ }^{1}$ A.Nuddin', Arman $^{3}$ \\ Email : Andinuruly81@gmail.com \\ Prodi Pertanian Agribisnis Fakultas Pertanian, Peternakan dan Perikanan \\ Universitas Muhammadiyah Parepare
}

\begin{abstract}
Te'tekan cake is one of the traditional foods in Enrekang Regency that can increase regional income, so it is necessary to know how te'tekan typical cake business income, how the feasibility of te'tekan typical cake business and how the development strategy by using income analysis method feasibility analysis and interpretativ analysis Stuktural Modelling ISM by taking data through interviews by filling out questionnaires for income and feasibility analysis of 30 respondents and 12 respondents for ISM analysis. The results of this study showed that the income level of te'press cake business in the Village Able District Anggeraja Enrekang regency as much as Rp.18.798.400 / production with a feasibility level of 1.58 and. The results of ISM analysis obtained strategic strategy programs are: (1) production technology development, (2) promotion and marketing, (3) business development, (4) product quality improvement
\end{abstract}

Keywords : Te'tekan Typical Cake Business, Income, Feasibility Level, Development Strategy

\begin{abstract}
ABSTRAK
Kue khas te'tekan merupakan salah satu makanan tradisional yang ada di Kabupaten Enrekang yang dapat menambah pendapatan Daerah, sehingga perlu diketahui bagaimana pendapatan usaha kue khas te'tekan bagaimana kelayakan usaha kue khas te'tekan dan bagaimana strategi pengembangannya dengan menggunakan metode analisis pendapatan analisis kelayakan dan analisis Interpretativ Stuktural Modelling ISM dengan pengambilan data melalui wawancara dengan pengisian kuisioner untuk analisis pendapatan dan kelayakan sebanyak 30 orang responden dan 12 responden untuk analisis ISM. Hasil penelitian ini menunjukan bahwa tingkat pendapatan usaha kue khas te'tekan di Desa Mampu Kecamatan Anggeraja Kabupaten Enrekang sebanyak Rp.18.798.400/produksi dengan tingkat kelayakannya 1.58 dan. Hasil analisis ISM diperoleh program strategi yang strategis adalah : (1) pengembangan teknologi produksi, (2) promosi dan pemasaran, (3) pengembangan usaha, (4) peningkatan kualitas produk
\end{abstract} Kata Kunci : Usaha Kue Khas Te’tekan, Pendapatan, Tingkat Kelayakan, Strategi Pengembangan

\section{A. PENDAHULUAN}

Enrekang merupakan salah satu daerah yang mempuyai aneka ragam jenis makanan tradisional. Setiap daerah di Enrekang memiliki makanan tradisional dengan ciri khasnya masing-masing meskipun ada yang sama, tetapi setiap daerah memiliki cita rasanya sendiri. Kue khas te'tekan merupakan salah satu makanan tradisional yang ada di 
Kabupaten Enrekang. Kue khas ini biasanya di komsumsi sebagai makanan pelengkap dan cemilan wajib masyarakat Enrekang pada hari-hari besar keagamaan seperti Idul fitri, Idul ahda, Maulid Nabi dan acara keluarga. Kue khas ini juga di jadikan ajang promosi untuk memperkenalkan makanan tradisional yang ada di Kabupaten Enrekang sehingga dapat dijadikan oleh-oleh bagi warga masyarakat yang berkunjung ke kabupaten Enrekang.

Kegiatan usaha kecil merupakan bagian dari sektor informal yang mempunyai kedudukan dan peran yang strategis dalam mewujudkan pembangunan. Khususnya usaha kecil di daerah pedesaan mendapat tempat yang baik dan tanggapan positif oleh masyarakat pedesaan. Usaha kecil adalah usaha yang menggunakan alat produksi sederhana yang telah diturunkan secara turun-temurun dan atau yang berkaitan dengan seni budaya (Anoraga, 2002).

Usaha kecil yang di kembangkan oleh masyarakat Enrekang khususnya ibu rumah tangga di Desa Mampu Kecamatan Anggeraja Kabupaten Enrekang. Adalah kue khas te'tekan yang merupakan kue khas dari daerah Enrekang dan termasuk usaha kecil atau home industry karena dikelola dengan skala yang kecil.
Kemampuan dan keterampilan pemilik usaha dalam mengelolah dan memproduksi kue khas te'tekan yaitu karena diperoleh dari warisan secara turuntemurun. Pemilik usaha melakukan pekerjaan dengan tujuan memperoleh dan menambah pendapatan keluarga untuk pemenuhan kebutuhan sehari-hari, karena itu para pemilik usaha sering dihadapkan pada persoalan tentang bagaimana mencapai keberhasilan usaha, serta strategi pengembangan.

Berdasarkan latar belakang, dapat dirumuskan masalah penelitian antara lain : 1) Bagaimana tingkat kelayakan usaha kue khas te'tekan di Kabupaten Enrekang, 2) Bagaimana strategi pengembangan usaha kue khas te'tekan di Kabupaten Enrekang?

\section{B. METODE PENELITIAN}

\section{Tempat dan Waktu}

Penelitian ini dilaksanakan selama dua bulan yaitu pada bulan Agustus sampai Oktober 2020. Di Desa Mampu Kecamatan Anggeraja Kabupaten Enrekang, sebagai dasar pertimbangan mata pencaharian sebagian besar masyarakat ialah usaha kue khas te'tekan.

\section{Populasi dan Sampel}

Menurut Sugiyono (2015), "mengemukakan bahwa populasi adalah wilayah generalisasi yang terdiri atas : 
subjek/objek yang mempunyai kualitas dan karakteristik tertentu yang ditetapkan oleh peneliti untuk dipelajari dan kemudian ditarik kesimpulannya"

Populasi dalam penelitian adalah semua pelaku usaha kue khas te'tekan yang berjumlah 30 pelaku usaha. Karena populasi dalam penelitian ini hanya 30 maka populasi yang di masukan sebagai sampel. Dari populasi disesuaikan dengan pendapat (Sugiyono, 2015) “ sampel adalah bangian dari populasi (sebagian atau wakil populasi yang diteliti)". Penentuan responden dalam penelitian ISM. Dilakukan melalui sistem ahli pakar dengan menggunakan metode survey. Penetapan responden dilakukan secara sengaja (purposive sampling), dengan ketentuan mewakili personil dibidang instansi yang terkait.

\section{Analisis Data}

Menurut (Sugiyono, 2015) “Analisis data adalah proses mencari dan menyusun secara sistematis data yang diperoleh dari hasil wawancara, catatan, lapangan, dan dokumentasi, dengan cara mengorganisasikan data ke dalam kategori, menjabarkan ke dalam unit-unit, melakukan sintesa, menyusun kedalam pola, memilih mana yang penting dan yang akan dipelajari dan membuat kesimpulan sehingga mudah dipahami oleh diri sendiri maupun orang lain"

Untuk menganalisis data dalam penelitian ini digunakan analisis deskriftif kuantitatif diperlukan untuk mengetahui keadaan usaha kue khas te'tekan tersebut secara financial seperti pendapatan usaha, R/C Ratio dan ISM. Analisis data yang digunakan dalam penelitian ini, adalah :

a. Biaya produksi, total biaya merupakan keseluruhan jumlah biaya produksi yang dikeluarkan (Firdaus, 2008). Total biaya dihitung dengan rumus :

$$
\mathbf{T C}=\mathbf{T F C}+\mathbf{T V C}
$$

Keterangan :

TC $($ total cost $)=$ Total Biaya Produksi (Rp)

TFC $($ Total Fixed Cost $)=$ Total Biaya Tetap (Rp)

TVC $($ Total Variable Cost $) \quad=$

Total Biaya Variabel (Rp)

b. Penerimaan adalah hasil penjualan dari sejumlah barang tertentu yang diterima atas penyerahan sejumlah barang kepada pihak lain dapat dihitung menggunakan rumus $: \mathbf{T R}=\mathbf{P}$ . Q

Keterangan :

$\mathrm{TR}=$ Total Revenue $($ Total Penerimaan)

$\mathrm{P}=$ Price ( Harga)

Q = Quantity (Jumlah Penjualan). 
c. Pendapatan usaha responden dapat dianalisis dengan menggunakan rumus sebagai berikut (Soekarwati, 2006).

$\pi=\mathbf{T R}-\mathbf{T C}$

Keterangan :

$\pi=$ Pendapatan $(\mathrm{Rp})$

$\mathrm{TR}=$ Total Penerimaan $(\mathrm{Rp})$

$\mathrm{TC}=$ Total Biaya $(\mathrm{Rp})$

d. Untuk menentukan tingkat kelayakan usaha responden dapat ditentukan dengan menggunakan rumus :

$\mathrm{R} / \mathrm{C}$ Ratio $=\frac{\mathrm{TR}}{\mathrm{TC}}$

Keterangan :

$\mathrm{R} / \mathrm{C}=$ Retum Cost Rasio

$\mathrm{TR}=$ Total Penerimaan $($ Total

Revenue)

$\mathrm{TC}=$ Total Biaya $($ Total Cost)

e. Interpretative Structural Modeling (ISM)

Analisis data menggunakan metode Interpretative Stuctural Modelling adalah kumpulan pendapat pakar sebagai panelis sewaktu menjawab tentang keterkaitan antar-elemen. Permodelan Interpretasi Struktural menganalisis elemen-elemen sistem dan memecahkannya dalam bentuk grafik dari hubungan langsung antar elemen. Elemen-elemen dapat merupakan tujuan kebijakan, target organisasi, faktorfaktor penilaian dan lain-lain. Hubungan langsung dapat dalam konteks-konteks yang beragam (Marimin, 2008).

Teknik ISM ini ini dapat digunakan untuk melakukan analisis data. Secara garis besar teknik ISM, langkah pertama yang perlu dilakukan dalam analisis ISM adalah menentukan elemen-elemen yang sesuai dengan permasalahan yang ada. Selanjutnya disusun sub-elemen pada setiap elemen yang dipilih. Pemilihan elemen dan penyusunan sub elemen dilakukan dari hasil diskusi di setiap instansi yang terkait. Hasil penilaian tersebut tersusun dalam Structural Self Interaction Matrix (SSIM) dalam bentuk Rechability Matrix (RM) dengan mengganti $\mathrm{V}, \mathrm{A}, \mathrm{X}, \mathrm{O}$ menjadi bilangan 1 dan 0 .

$\mathrm{V}=$ adalah eij adalah 1 eij adalah 0

$\mathrm{A}=$ adalah eij adalah 0 dan eij adalah 1 $\mathrm{X}=$ adalah eij adalah 1 dan eij adalah 1 $\mathrm{O}=$ adalah eij adalah 0 dan eij adalah 0 1 adalah hubungan konsektual antara elemen

0 = tidak ada hubungan konsektual antar elemen

Nilai 1 berarti ada hubungan kontekstual antara elemen ke-I dan elemen ke-j, sedangkan eij $=0$ berarti tidak ada hubungan konstektual antar elemen ke-I dengan elemen ke-j. kemudian SSM diubah menjadi Reachability Matrix 
dengan menrubah VAXO menjadi 1 dan 0 , selanjutnya dilakukan pengujian terhadap aturan transivity, matrix Reachability, untuk mendapatkan matrix Reachability, untuk mendapatkan Driver Power (DP) dan Dependent (D). tahap terakhir adalah pengelompokan sub-sub elemen kedalam 4 sektor ( Saxena, 1994 dalam Eriyatno 1999).

a. Weak Driver- weak Dependent Variables (AUTONOMOUS), pengubah di sektor ini umumnya tidak berkaitan dengan system, hubungannya sedikit.

b. Weak Driver Strongly- Dependent Variables (DEPENDENT), pengubah yang masuk kedalam kelompok ini merupakan pengubah tak bebas. c. Strong Driver Strongly Dependent Variables (LINKAGE), pengubah pada sektor ini harus dikaji secara hati-hati karena interaksinya dapat memberikan dampak dan umpan balik terhadap system.

d. Strong Driver Weak Dependent Variables (INDEPENDENT) pengubah dalam sektor ini memiliki pengaruh sangat kuat dalam sistem dan sangat menentukan keberhasilan program.

\section{HASIL DAN PEMBAHASAN}

\section{Biaya Variabel}

Biaya variabel merupakan biaya yang di pengaruhi terhadap besar kecilnya produksi suatu usaha. Dimana biaya yang dikeluarakan mengikuti pertambahan atau pengurangan bahan produksi.

\section{Tabel 1. Rata -rata Biaya Variabel Pelaku Usaha Kue Khas Te'tekan}

\begin{tabular}{clcr}
\hline No & Biaya Variabel & Jumlah Rata-rata & Nilai (Rp) \\
\hline 1 & Minyak goring & $12.23 \mathrm{Ltr}$ & 160.033 \\
2 & Tepung beras & $14.26 \mathrm{Kg}$ & 199.733 \\
3 & Isi tabung & 1.10 & 22.000 \\
4 & Gula aren & $12.40 \mathrm{Kg}$ & 184.333 \\
5 & Kemasan & 57.06 & 28.533 \\
6 & Wijen & $0.73 \mathrm{Kg}$ & 35.833 \\
7 & Upah & 1.40 & 140.000 \\
\hline \multicolumn{2}{c}{ Jumlah Rata-rata } \\
\hline
\end{tabular}

Sumber: Data Setelah Diolah, (2020)

Rata - rata biaya yang dikeluarkan oleh 30 pelaku usaha kue khas te'tekan di Kabupaten Enrekang yaitu sebesar Rp. 770.466

\section{Biaya Tetap}

Biaya tetap adalah biaya yang secara total tidak mengalami perubahan. Walaupun ada perubahan banyaknya 
produksi atau penjualan dalam batas tertentu biaya pada dasarnya mempunyai arti jangka pendek dimana faktor-faktor produksi yang digunakan mempunyai faktor produksi tetap (Suratiyah, 2008).

Biaya tetap usaha kue khas te'tekan yang termasuk didalamnya adalah pajak, dan penyusutan alat serta biaya lainnya. Jumlah biaya tetap yang digunakan oleh pelaku usaha kue khas te'tekan di Kabupaten Enrekang dapat dilihat pada tabel 2 .

\section{Tabel 2. Rata -rata Biaya Tetap Pelaku Usaha Kue Khas Te'tekan}

\begin{tabular}{cccc}
\hline No & Biaya Tetap & Jumlah (Rp) & Rata-rata (Rp) \\
\hline 1 & Pajak & 300.000 & 10.000 \\
2 & Penyusutan & 9.147 .600 & 304.920 \\
\hline & Jumlah Rata-rata & $\mathbf{9 . 4 4 7 . 6 0 0}$ & $\mathbf{3 1 4 . 9 2 0}$ \\
\hline
\end{tabular}

Sumber: Data Setelah Diolah, (2020)

Pada tabel 2 biaya rata-rata yang dikeluarkan oleh 30 pelaku usaha kue khas te'tekan di Desa Mampu Kecamatan Anggeraja Kabupaten Enrekang adalah Rp. 314.920 jumah biaya tersebut disesuaikan dengan berapa besar biaya yang dikeluarkan pada pengeluaran alat masing-masing responden.

\section{Total Biaya Produksi}

Menurut (Sukirno, 2013) "mengemukakan bahwa biaya produksi adalah semua pengeluaran yang dilakukan oleh perusahaan untuk memperoleh faktorfaktor produksi dan bahan-bahan mentah yang akan digunakan untuk menciptakan barang-barang yang diproduksi perusahaan tersebut" Biaya produksi adalah sejumlah pengorbanan yang dinilai dengan uang yang dikeluarkan untuk memproduksi suatu barang atau jasa untuk menambah nilai guna suatu barang pada suatu periode tertentu.

Usaha kue khas te'tekan dalam menjalankan produksinya akan mengeluarkan sejumlah biaya mulai pada saat persiapan (menyiapkan alat dan bahan pengolahan lainnya), pelaksanaan usaha hingga pada saat pemasaran atau pada kegiatan menyalurkan hasil produksi kue khas te'tekan ke konsumen. Sehingga jika dikaitkan dengan biaya produksi maka dapat disimpulkan biaya usaha kue khas te'tekan

adalah keseluruhan biaya yang dikeluarkan oleh pemilik usaha kue khas te'tekan mulai pada saat akan menyiapakan usaha sampai pada saat mendapatkan hasil produksi.

\section{Tabel 3. Rata-rata Total Biaya Produksi Pelaku Usaha Kue Khas Te'tekan}




\begin{tabular}{llcc}
\hline No & Jenis Biaya & Jumlah $(\mathrm{Rp})$ & Rata-rata $(\mathrm{Rp})$ \\
\hline 1 & Biaya Variabel & 23.144 .000 & 770.466 \\
2 & Biaya Tetap & 9.447 .600 & 314.920 \\
\hline & Jumlah & $\mathbf{3 2 . 5 9 1 . 6 0 0}$ & $\mathbf{1 . 0 8 5 . 3 8 6}$ \\
\hline
\end{tabular}

. Sumber: Data Setelah Diolah, (2020)

Tabel 3 menunjukan rata-rata biaya yang dikeluarkan usaha responden di Desa Mampu Kecamatan Anggeraja Kabupaten Enrekang dengan biaya variabel Rp.23.144.000 dengan biaya tetap Rp.9.447.600 sama dengan Rp.32.591.600 dengan biaya rata-rata yang dikeluarkan oleh pelaku usaha kue khas Te'tekan sebesar Rp.1.085.386.

\section{Kelayakan}

Kelayakan merupakan penilaian yang menyeluruh untuk menilai keberhasilan suatu proyek. Dan studi kelayakan proyek mempunyai tujuan untuk menghindari keterlanjuran penanaman modal yang terlalu besar untuk kegiatan yang ternyata tidak menguntungkan. Studi kelayakan atau bisnis merupakan suatu kegiatan mengevaluasi, menganalisis, dan menilai layak atau tidaknya suatu proyek bisnis dijalankan (Jumingan, 2009).

Kelayakan usaha kue khas te'tekan yang dilakukan oleh pelaku usaha kue khas di Desa Mampu Kecamatan Anggeraja Kabupaten Enrekang dengan menggunkan rumus R/S Ratio

\section{Tabel 4. Rata-rata Total Biaya Tetap Pelaku Usaha Kue Khas Te'tekan}

\begin{tabular}{llcc}
\hline No & Uraian & Jumlah (Rp) & Rata-rata (Rp) \\
\hline 1 & Penerimaan & 51.360 .000 & 1.712 .000 \\
2 & Biaya & 32.561 .600 & 1.085 .386 \\
\hline \multicolumn{5}{r}{} & Jumlah & $\mathbf{1 . 5 8}$ \\
\hline
\end{tabular}

Sumber: Data Setelah Diolah, (2020)

Tabel 4 menunjukkan bahwa Nilai R/S Ratio yang diperoleh sebesar Rp. 1.58 berdasarkan kreteria R/S Ratio >1, maka usaha tersebut layak unruk dikembangkan atau diusahakan , jadi setiap pengeluaran Rp. 1,- akan diperoleh penerimaan sebesar 1.58 ,- dengan melihat jumlah usaha yang diperoleh tersebut maka secara ekonomis layak untuk dikembangkan

\section{Strategi Pengembangan}

Program strategi pengembangan usaha kue khas te'tekan di Kabupaten Enrekang. Hasil analisis Interpretative Stuktural Modelling (ISM). Usaha kue khas te'tekan menunjukan bahwa 10 subelemen, 8 diantaranya merupakan program yang berperan penting dalam strategi pengembangan usaha kue khas te'tekan. 4 
diantaranya memiliki daya penggerak

(Driver power) seperti pada tabel 5.

Tabel 5. Perbandingan Bobot DP-D Program Strategi Pengembangan Usaha Kue Khas Te'tekan

\begin{tabular}{llll}
\hline \multirow{2}{*}{ Posisi } & \multicolumn{1}{c}{ Sub Elemen } & \multicolumn{2}{c}{ Bobot } \\
\cline { 3 - 4 } & & DP & D \\
\hline Linkage & 1. Pengembangan teknologi produksi & $1,0^{*}$ & 0,6 \\
& 2. Promosi dan pemasaran & 1,0 & 0,6 \\
& 3. Pengembangan usaha & 1,0 & 0,6 \\
& 4. Peningkatan kualitas produk & 1,0 & 0,7 \\
& 5. Program pendidikan dan pelatihan & 0,8 & 0,3 \\
& 6. Peningkatan peran penyuluh & 0,7 & 0,6 \\
& 7. Pengembangan mutu kemasan & 0,6 & 0,7 \\
& 8. Pengembangan merek produk/ikon daerah & 0,6 & 1,0 \\
\hline Dependent & 9. Penganekaragaman bentuk dan model produk & 1 & 0,8 \\
& 10. Pengstabilan harga & 0,2 & 0,9 \\
\hline
\end{tabular}

Keterangan : DP (Driver Power). D (Dependent), *) Program Prioritas Kunci

\section{a. Program Strategis diposisi Linkage}

Hasil analisis Interpretative

Struktural Modelling (ISM) Menunjukan

bahwa ada 8 program strategis yang berada pada posisi linkage, diantaranya adalah sub elemen : 4. Pengembangan teknologi produksi, 8. Promosi dan pemasaran, 9. Pengembangan usaha, 2. Peningkatan kualitas produk, 10. Program pendidikan dan pelatihan, 6. Peningkatan peran penyuluh/pendampingan,

Pengembangan mutu pengemasan, 1. Pengembangan produk ikon/daerah.

Program srategi pengembangan usaha kue khas Te'tekan yang berada pada posisi linkage adalah pengembangan teknologi produksi. Pengembangan teknologi meliputi perkembangan teknologi produksi, perkembangan teknologi komunikasi, dan perkembangan teknologi tranportasi. Jenis teknologi digolongkan menjadi dua yaitu teknologi jaman dahulu (tradisional) dan jaman sekarang (modern). Teknologi tradisional masih menggantungkan pada tenaga hewan, angin dan manusia, sedangkan teknologi modern sudah memanfaatkan tenaga mesin (Pujianti dan Yulianti, 2008).

Program srategi selanjutnya adalah promosi dan pemasaran, selain modal, materi, dan niat yang kuat dibutuhkan juga strategi yang jitu untuk menghadapi persaingan. Salah satu strategi marketing yang dijamak, diaplikasikan oleh pelaku usaha adalah promosi (media sosial) melalui promosi ini konsumen akan lebih 
tertarik akan produk kue khas te'tekan ini. Promosi adalah arus informasi atau persuasi satu arah yang dapat dibuat untuk mengarahkan seseorang atau organisasi kepada tindakan menciptakan pertukaran dalam pemasaran (Swastha dan Irawan, 2001).

Program strategi selanjutnya adalah pengembangan usaha. Pengembangan usaha. Merupakan salah satu kegiatan membuat suatu usaha lebih stabil, layaknya usaha kue khas te'tekan dengan adanya perhatian khusus terhadap kegiatan usaha ini, sehingga pengembangan diluar usaha kue khas te'tekan juga dapat menambah pendapatan usaha seperti penjualan baje, dodol, kripik dan lain sebagainya

Program strategis selanjutnya ialah peningkatan kualiatas produk. Saat ini perkembangan dunia bisnis telah mengalami banyak kemajuan yang cukup pesat sehingga mendorong persaingan antar perusahaan semakin meningkat. dengan adanya fenomena tersebut kita dituntut untuk dapat bersaing dalam menciptakan produk unggul yang dapat laku dipasaran. Produk yang berkualitas tinggi adalah kunci utama dalam memenangkan persaingan. Kualitas produk merupakan suatu ciri dari tempat yang mana pelanggan akan merasa puas saat melakukan pembelian maupun mengkomsumsi produk tersebut. Ketika pelanggan merasa puas dengan produk yang ia beli pelanggan akan loyal dan akan melakukan pembelian ulang.

Program strategi selanjutnya adalah program pendidikan dan pelatihan, manusia memiliki sejumlah kemampuan yang dapat dikembangkan melalui pendidikan dan pengalaman. Pengalaman itu terjadi karena interaksi manusia dengan lingkungannya, baik lingkungan fisik maupun lingkungan sosial manusia secara efektif. Kegiatan pelatihan memberikan memberikan manfaat yang cukup besar bagi peserta pelatihan apabila dikelolah dengan baik. Banyak orang telah memanfaatkan pelatihan untuk membantu mereka dalam melaksanakan berbagai tugas dalam kehidupan, pada hakikatnya pelatihan merupakan pemberian pengalaman kepada seseorang untuk mengembangkan tingkah laku dalam hal ini skill dan sikap agar mencapai sesuatu yang diinginkan (Robinson, 1981).

$$
\text { Peningkatan }
$$

peran penyuluh/pendampingan merupakan agen perubahan yang langsung berhubungan dengan pelaku usaha. Fungsi utamanya yaitu mengubah perilaku pelaku usaha kue khas te'tekan dengan pendidikan non formal sehingga dapat memberikan hal 
yang baru secara berkelanjutan. Penyuluh dapat mempengaruhi sasaran dan peranannya sebagai motivator, educator, dinamisator, kominikator, maupun sebagai penasehat (Jermie 2000).

Pengembangan mutu pengemasan merupakan hal yang penting kerena kemasan tidak hanya digunakan sebagai pelindung terhadap produk, tetapi kemasan digunakan sebagai media promosi untuk memikat konsumen sehingga konsumen berkeputusan untuk melakukan pembelian produk yang bersangkutan. Menurut Kotler (2003) pengemasan merupakan kegiatan merancang dan membuat wadah atau bungkus sebagai suatu produk, sedang menurut Swasta, Basu (1999) mengatakan kemasan (packaging) adalah kegiatankegiatan yang bersifat umum dan perencanaan barang yang melibatkan penentuan bentuk atau desain pembuatan bungkus atau kemasan suatu barang. Jadi dapat dikatakan bahwa kemasan adalah suatu kegiatan merancang dan memproduksi bungkus suatu produk yang meliputi desain bungkus dan pembuatan bungkus produk tersebut.

Pengembangan merek produk ikon daerah adalah kemampuan dalam mengembangkan produk ikonik adalah produk yang menjadi ikon atau lambang yang bersifat spesifik yang menjadi daya pengigat konsumen dengan simbol-simbol yang terdapat pada produk tersebut (Fitriani, 2014). Jadi keunggulan produk ikon atau lambang yang menjadi daya pengigat konsumen dengan simbol-simbol yang terdapat pada produk tersebut.

\section{b. Program Strategi Dependent}

Hasil analisis Interpretatif Structural Modelling (ISM) menunjukan bahwa ada 2 program yang berada pada posisi dependent, 5. Penganekaragaman bentuk dan model produk, 7. Pengstabilan harga. Program yang ada diposisi ini tidak bebas artinya semua bergantung pada tindakan terhadap sub-elemen lainnya.

Kecilnya Driver power (DP) menunjukan idikasi bahwa sub-elemen tidak menjadi strategi pengembangan usaha kue khas Te'tekan, sedangkan dependent (D) menunjukan bahwa ketergantungannya terhadap sub-elemen lainnya besar artinya sub-elemen yang ada diposisi ini adalah tidak bebas karena itu sub-elemen yang ada diposisi ini tidak penting atau tidak menjadi strategi pengembangan usaha kue khas te'tekan.






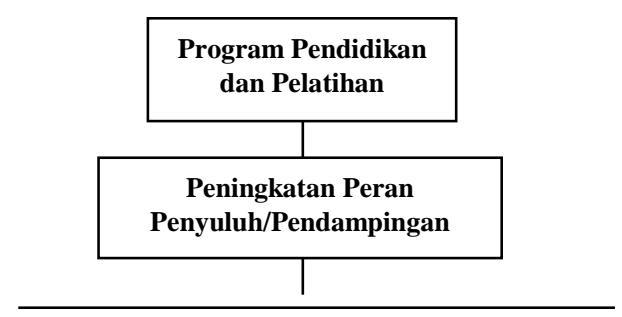

Gambar 1. Model structural Program Strategi yang perlu dilakukan untuk Pengembangan Usaha Kue Te'tekan

Gambar 1 menunjukan bahwa yang berada pada level 1 ada 4 strategi pengembangan usaha kue khas te'tekan yang berarti bahwa strategi pengembangan usaha kue te'tekan yang sangat diperlukan adalah adanya pengembangan teknologi produksi. Pengembangan teknologi yang paling penting bagi manusia salah satunya, saat ini teknologi produksi berperan dalam mempermudah atau mempercepat (pekerjaan) proses produksi. Perkembangan teknologi meliputi perkembangan teknologi produksi, perkembangan teknologi komunikasi, dan perkembangan teknologi tranportasi. Disamping promosi dan pemasaran, pengembangan usaha, peningkatan kualitas produk untuk mendukung pengembangan usaha kue khas te'tekan di Kabupaten Enrekang. Dimana strategi tersebut harus dilakukan untuk pengembangan usaha kue khas te'tekan oleh pemerintah.

\section{KESIMPULAN}

Berdasarkan hasil dan penelitian yang di lakukan di Desa Mampu Kecamatan Anggeraja Kabupaten Enrekang maka dapat disimpulkan sebagai berikut:

1. Kelayakan usaha kue khas te'tekan yang diperoleh sebesar 1.58 jadi setiap pengeluaran Rp. 1,- akan diperoleh penerimaan sebesar 1.58,- dengan melihat jumlah usaha te'tekan dapat dikatakan usaha tersebut menguntungkan secara ekonomis dan layak untuk diusahakan.

2. Program kegiatan yang strategis dalam upaya pengembangan usaha kue khas Te'tekan. Sebagai berikut :

a. pengembangan teknologi produksi, sangat berperan penting dalam mempermudah atau mempercepat (pekerjaan) proses produksi.

b. Promosi dan pemasaran, salah satu strategi marketing yang di jamak, 
diaplikasikan oleh pelaku usaha adalah promosi (media sosial), melalui promosi konsumen akan lebih mengetahui secara detail produk yang ada dipasaran.

c. Pengembangan usaha, merupakan salah satu kegiatan yang membuat usaha lebih stabil, layaknya kue khas te'tekan dengan adanya perhatian yang khusus terhadap kegiatan usaha ini, sehingga dapat memberikan nilai tambah yang lebih.

d. Peningkatan kualitas produk, Produk yang berkualitas tinggi adalah kunci utama dalam memenangkan persaingan. Kualitas produk merupakan suatu ciri dari tempat yang mana pelanggan akan merasa puas saat melakukan pembelian maupun mengkomsumsi produk tersebut.

e. Program pendidikan dan pelatihan, Kegiatan pelatihan memberikan manfaat yang cukup besar bagi peserta pelatihan apabila dikelolah dengan baik. Banyak orang telah memanfaatkan pelatihan untuk membantu mereka dalam melaksanakan berbagai tugas dalam kehidupan.

f. Peningkatan peran penyuluh/ pendampingan, Fungsi utamanya yaitu mengubah perilaku pelaku usaha kue khas te'tekan dengan pendidikan non formal sehingga dapat memberikan hal yang baru secara berkelanjutan.

g. Pengembangan mutu pengemasan, kemasan tidak hanya digunakan sebagai pelindung terhadap produk, tetapi kemasan digunakan juga sebagai media promosi untuk memikat konsumen.

h. Pengembangan merek produk/ikon daerah, yang menjadi ikon atau lambang yang bersifat spesifik yang menjadi daya pengigat konsumen dengan simbol-simbol yang terdapat pada produk tersebut

\section{DAFTAR PUSTAKA}

Anoraga. 2002. Koperasi Kewirausahaan, Dan Usaha Kecil. Jakarta: Rineka Cipta.

Basu Swastha, 1999 Manajemen Pemasaran Modern, Edisi Ketiga Yogyakarta, Liberty.

Eriyatno. 1999. Ilmu Sistem Meningkatkan Mutu dan Efektivitas Manajemen. IPB Press, Bogor, Hal 79

Firdaus, M.2008. Manajemen Agribisnis. PT. Bumi Aksara, Jakarta.

Fitriani, L.K. (2014). Produk Ikonik Akulturatif. Disertasi Program Doktor Ilmu Ekonomi Bidang Kajian Manajemen Pemasaran Universitas Diponegoro, Semarang : Penerbit Pustaka Magister. 
Jermie MJ. 2000. Peranan Imu Penyuluhan Menuju Pembangunan Pertanian Yang Berwawasan Agribisnis Dalam.

Jumingan, 2009. Studi Kelayakan Bisnis. Jakarta : Bumi Aksara

Marimin. 2008. Tenik dan Aplikasi Pengambilan Keputusan Kreteria Majemuk. Grassindo. Jakarta.

Philips Kolter, 2003. Manajemen Pemasaran Edisi Sebelas, Jakarta: PT. Indeks.

Pujianti, R. H. dan U. Yulianti. 2008. Cerdas Pengetahuan Sosial untuk SD/MI Kelas IV. Jakarta: Pusat Perbukuan Depdiknas.

Robinson. 1981 Chilid Develoment, New York: Holt Rinehart.

Sugiyono, 2015. Metode Penelitian Pendidikan Pendekatan Kuantitatif, Pendekatan Kualitatif dan $R \& D$. Edisi Kedua satu. Bandung: Alfabeta.
Sukirno, 2013. Mikro Ekonomi Teori Pengantar : PT. Radja Grafindo Persada.

Soekartawi, (2006: 85-86). Pembangunan Pertanian. Jakarta: PT. Raja Grafindo Persada. 